\title{
Archaeological Testing of Historic Sites to be Affected by Construction of IH 410 Through the San Antonio Missions National Park City of San Antonio, Bexar County, Texas
}

John W. Clark Jr.

Follow this and additional works at: https://scholarworks.sfasu.edu/ita

Part of the American Material Culture Commons, Archaeological Anthropology Commons, Environmental Studies Commons, Other American Studies Commons, Other Arts and Humanities Commons, Other History of Art, Architecture, and Archaeology Commons, and the United States History Commons

Tell us how this article helped you.

This Article is brought to you for free and open access by the Center for Regional Heritage Research at SFA ScholarWorks. It has been accepted for inclusion in Index of Texas Archaeology: Open Access Gray Literature from the Lone Star State by an authorized editor of SFA ScholarWorks. For more information, please contact cdsscholarworks@sfasu.edu. 


\section{Archaeological Testing of Historic Sites to be Affected by Construction of IH 410 Through the San Antonio Missions National Park City of San Antonio, Bexar County, Texas}

\section{Licensing Statement}

This is a work produced for the Texas Department of Transportation (TxDOT) by the report producer. TxDOT and the report producer jointly own all rights, title, and interest in and to all intellectual property developed under TXDOT's contract with the report producer. The report may be cited and brief passages from this publication may be reproduced without permission provided that credit is given to both TxDOT and the report producer. Permission to reprint an entire chapter, section, figures or tables must be obtained in advance from either the Supervisor of the Archeological Studies Branch, Environmental Affairs Division, Texas Department of Transportation, 125 East 11th Street, Austin, Texas, 78701 or from the report producer. 


\title{
ARCHAEOLOGICAL TESTING OF HISTORIC SITES TO BE AFFECTED BY CONSTRUCTION OF IH410 THROUGH THE SAN ANTONIO MISSIONS NATIONAL PARK CITY OF SAN ANTONIO, BEXAR COUNTY, TEXAS
}

\author{
B y \\ John W. Clark, Jr.
}


The State Department of Highways and Public Transportation plans to add access lanes along segments of Loop 410 (IH 410) in the City of San Antonio, Texas. The project traverses the acequia systems of Missions San Francisco de la Espada and San Juan Capistrano and also is adjacent to an historic site, 41BX252, which is the possible location of some historical structures. Backhoe trenching and hand excavation, conducted on December 8 and 9, 1986, produced no nineteenth century or Spanish Colonial materials, and also revealed that the segments of the acequias and desagues (laterals) within the project right-of-way had been disturbed by previous highway construction to the extent that they do not meet eligibility requirements for nomination to the National Register of Historic Places nor designation as State Archeological Landmarks. No further work is recommended on this project. 
TABLE OF CONTENTS

ABSTRACT . . . . . . . . . . . . . . . . 1

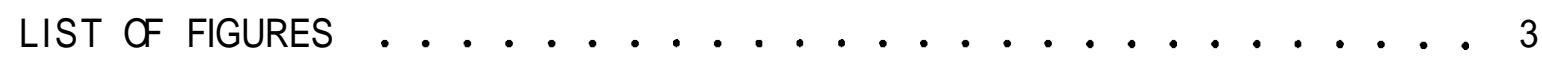

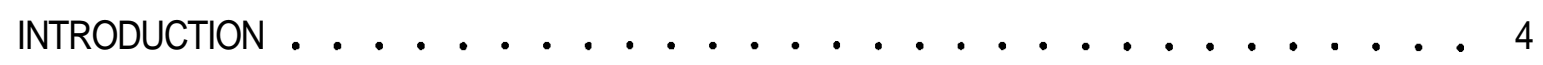

ARCHAEOLOGICAL BACKGROUND . . . . . . . . . . 6

HISTORICAL BACKGROUND................ 8

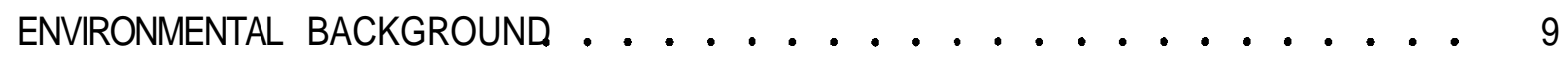

OBJECTIVES AND METHODS OF TESTING . . . . . . . . 10

TESTING RESULTS . . . . . . . . . . . . . . 16

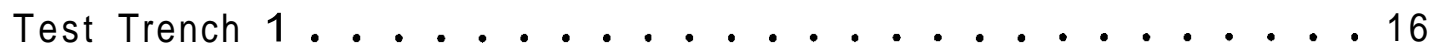

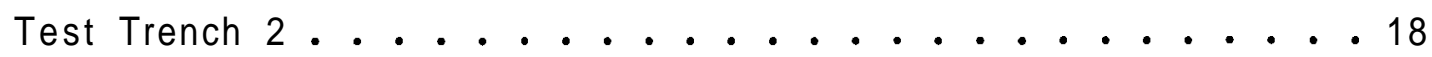

Test Trench $4 \ldots \ldots \ldots$

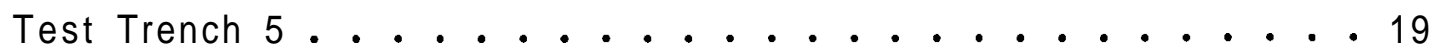

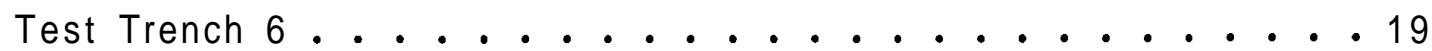

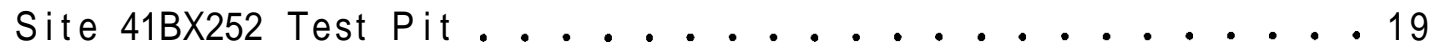

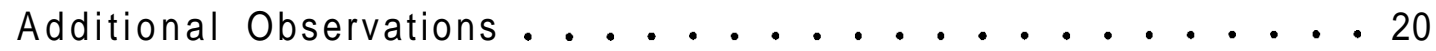

REFERENCES CITED . . . . . . . . . . . . . . . . . . 22 


\section{LIST OF FIGURES}

FIGURE 1. Location of IH 410 project in the City of San Antonio, Bexar County, Texas............... 5

FIGURE 2. Location of backhoe test trenches near the Espada acequia madre and test pit near Site 41BX252 . . . . . 11

FIGURE 3. Location of test pit near the Espada desague and

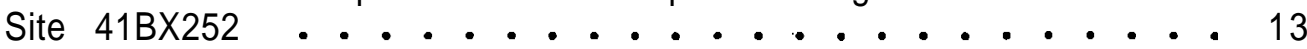

FIGURE 4. Location of backhoe test trenches traversing the San Juan acequiamadre............................ 14

FIGURE 5. Location of backhoe test trench traversing the San Juan

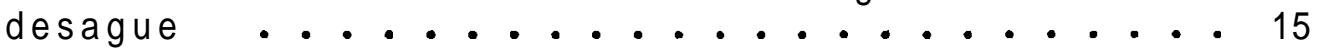

FIGURE 6. Profiles of test trenches excavated along IH 410 . . . 17 
INTRODUCTION

The Texas State Department of Highways and Public Transportation (SDHPT) District 15 requested an archaeological survey of Interstate Highway 410 (Loop 410) in south San Antonio where the SDHPT is planning to add access lanes to the freeway (Fig. 1). A portion of the project passes through the San Antonio Missions National Park, traverses the acequia (irrigation ditch) systems of Missions San Francisco de I a Espada and San Juan Capistrano, and is adjacent to an historic site, 41BX252, identified in a previous archaeological survey of the National Park (Scurlock et al. $1976)$.

A preliminary survey, locating these and other sites outside the National Park, was conducted by Alfred Joachim McGraw. The sites outside the park were found to be disturbed and not to meet the criteria for nomination to the National Register of Historic Places. Prior to the testing herein reported, an on-site meeting was held which included participants from the SDHPT Highway Design Division, District 15, the Federal Highway Administration, the office of the State Historic Preservation Officer, the National Park Service, the City of San Antonio Historic Preservation Office, and the San Antonio River Authority. It was agreed that backhoe trenches would be dug at the acequias madre of Missions Espada and San Juan and at the two associated desagues (laterals), and that testing would take place at 41BX252. This investigation took place on December 8 and 9, 1986, and entailed 12 work-hours for the archaeologist and 8 hours for the machine operator and his assistant, for a total of 20 person-hours spent on the project. 
This Page Redacted Per THC Policy 
Archaeological investigations at the San Antonio missions began with the restoration activities of San Antonio architect Harvey P. Smith, Sr., during the 1930s. His trenching to locate and expose foundation walls at San Jose y San Miguel de Aguayo produced a number of artifacts and exposed the foundations of the Indian apartments, the grist mill, and several workshops.

Subsequent work at the missions and their support facilities has been on a project-by-project basis aimed at mitigating the effects of particular projects. Work has been done at San Antonio de Valero (Greer 1967; Schuetz 1966; Tunnell 1966; Sorrow 1972; Fox, Bass, and Hester 1976; Eaton 1980), San Jose (Schuetz 1970; Fox 1970; Clark 1978; Clark and Prewitt 1979; Henderson and Clark 1984), San Juan (Schuetz 1968, 1969, 1974), Concepcion (Scurlock and Fox 1977), and Espada (Fox and Hester 1976).

There have been several projects at these missions that remain unreported. These include work at San Antonio de Valero by the University of Texas at San Antonio (UTSA), work at Concepcion--also by UTSA, work at San Jose including monitoring by the Texas Parks and Wildlife Department and UTSA, testing a Colonial Period dump at San Juan (Clark n.d.), excavations and architectural work at San Juan by Miguel Celorio and Dan Scurlock, excavation at Espada by UTSA, and work on the kilns at Espada by Scurlock and by UTSA. 
Work on the several acequia systems also has been performed. These include Schuetz (1970), Sorrow (1972), Fox (1978, 1985), Frkuska (1981), Cox (1986), and the historical studies by Holmes (1962) and Glick (1972). During preliminary work prior to testing, the SDHPT collected a number of primary documents from the Bexar Archives relating to the suertes and acequias of the San Juan and Espada missions.

It should be noted that, relative to the resource, all of these projects have been minor and related to specific development projects impacting the missions or their dependencies. Only the Holmes and Glick studies consider major subject areas. 


\section{HISTORICAL BACKGROUND}

San Juan Mission was originally established as San Jose de lo s Nazonis, north of Nacogdoches. Because of war with France and the impossibility of congregating the Indians due to agricultural problems associated with area geomorphology, the mission was moved presumably to the Colorado River in 1730 and then to San Antonio in 1731. It was renamed San Juan Capistrano. The acequia was begun at that time. The mission served regional Coahuilatecan bands. Partial secularization took place in 1794 with final partition in 1823 and 1831.

San Francisco de I a Espada was established as San Francisco de los Tejas in 1690 near Neches, Texas. The mission failed due to epidemics and a poor economic base and was re-established near Alto in 1716 as Nuestro Padre San Francisco de los Tejas. It existed there until 1719. Another attempt was made in 1721 in the same area. It was renamed San Francisco de los Weches. It was moved to San Antonio in 1731, becoming San Francisco de I a Espada. Secularization took place between 1794 and 1823. 


\section{ENVIRONMENTAL BACKGROUND}

The geology of the area consists of cretaceous limestones, marls, travertine, and sands overlain with Lewisville-Houston black terrace deposits of deep calcareous clay in the areas outside the river bottoms and VenusFrio-Trinity deep calcareous clays on the creek and river bottom lands (Taylor, Hailey, and Richmond 1966:127). The missions lie at the north edge of the South Texas Plains and the south edge of the Blackland Prairies (Gould 1969:11-12). Mammals of the area are described by Davis (1978), and the climate and physiography are discussed by Carr (1967). 


\section{OBJECTIVES AND METHODS OF TESTING}

In general there were two primary goals of the testing of specific features in the project area. The first was to discover if there were intact cultural deposits greater in age than 50 years in or adjacent to the features, and the second was to define the profiles of any undisturbed acequia features. If data warranted, the results of the testing would lead to an evaluation of the National Register eligibility of the segments of the features lying within the right-of-way and to proposals for mitigation of the impact of the construction.

It was agreed that the Espada acequia madre, the Espada desague, the San Juan acequia madre, and the San Juan desague would be trenched by backhoe and Site 41BX252 would be hand-tested in that part of the site that remained in the right-of-way. The trenching was done in two ways. At the Espada acequia madre, two trenches were dug adjacent to the bank so as not to cause silting in the floor of the ditch and not to interfere with the flow of water (Fig. 2). In the other areas where the acequia and desague were not in use, the trenches traversed the feature. Each test trench was given a number and was recorded with profile drawings of the south faces of the trenches and with photographs. When artifacts were noted, they were collected in a bag labeled with the provenience of the material.

The first trench, situated on the south side of $1 \mathrm{H} 410$ and on the west side of the Espada acequia madre, was labeled TT 1. The trench on the east side of the acequia was $\Pi 2$ (Fig. 2). It was planned that $\Pi 3$ would be on the north side of IH 410 traversing the Espada desague. It was discovered, 


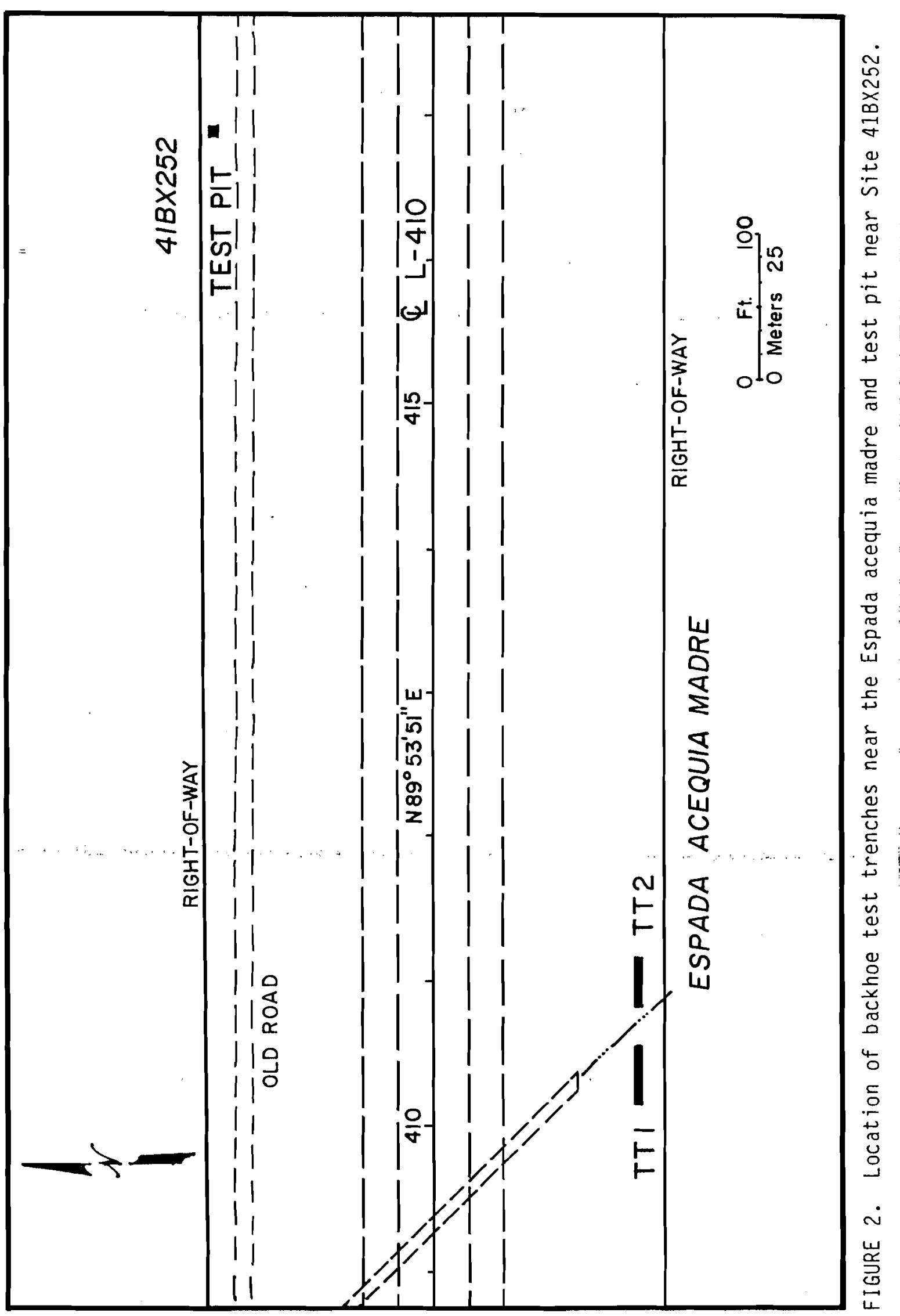


however, that a 36-in. concrete pipe occupied the former channel of this desague (Fig. 3). That being the case, demonstrated by documentation provided by SDHPT District 15, it was decided not to excavate TT 3 (Fig. 3).

Tा 4 (Fig. 4) was situated on the north side of IH 410 traversing the San Juan acequia madre, while $\Pi 5$ (Fig. 4) was situated on the south side traversing the same acequia. The final trench, TT 6 (Fig. 5), was situated on the San Juan desague on the south side of $\mathrm{IH} 410$.

Hand testing of Site 41BX252 (Figs. 2 and 3) consisted of the excavation of a 1-by 1-meter test pit to a depth of $5-10 \mathrm{~cm}$ below the surface. The test pit was located on the north edge of the right-of-way. Excavated deposits were passed through a 0.25 -in. mesh hardware cloth screen. Artifacts encountered were placed in an appropriately labeled bag. They were subsequently washed, labeled, and cataloged.

In addition to the above-cited efforts, a collection of documents relating to the Mission San Juan and Espada acequia and suerte systems was obtained from the Bexar Archives in San Antonio. This preliminary research was done so as to have a part of the archival research accomplished in case the archaeological testing warranted further work in the area. 


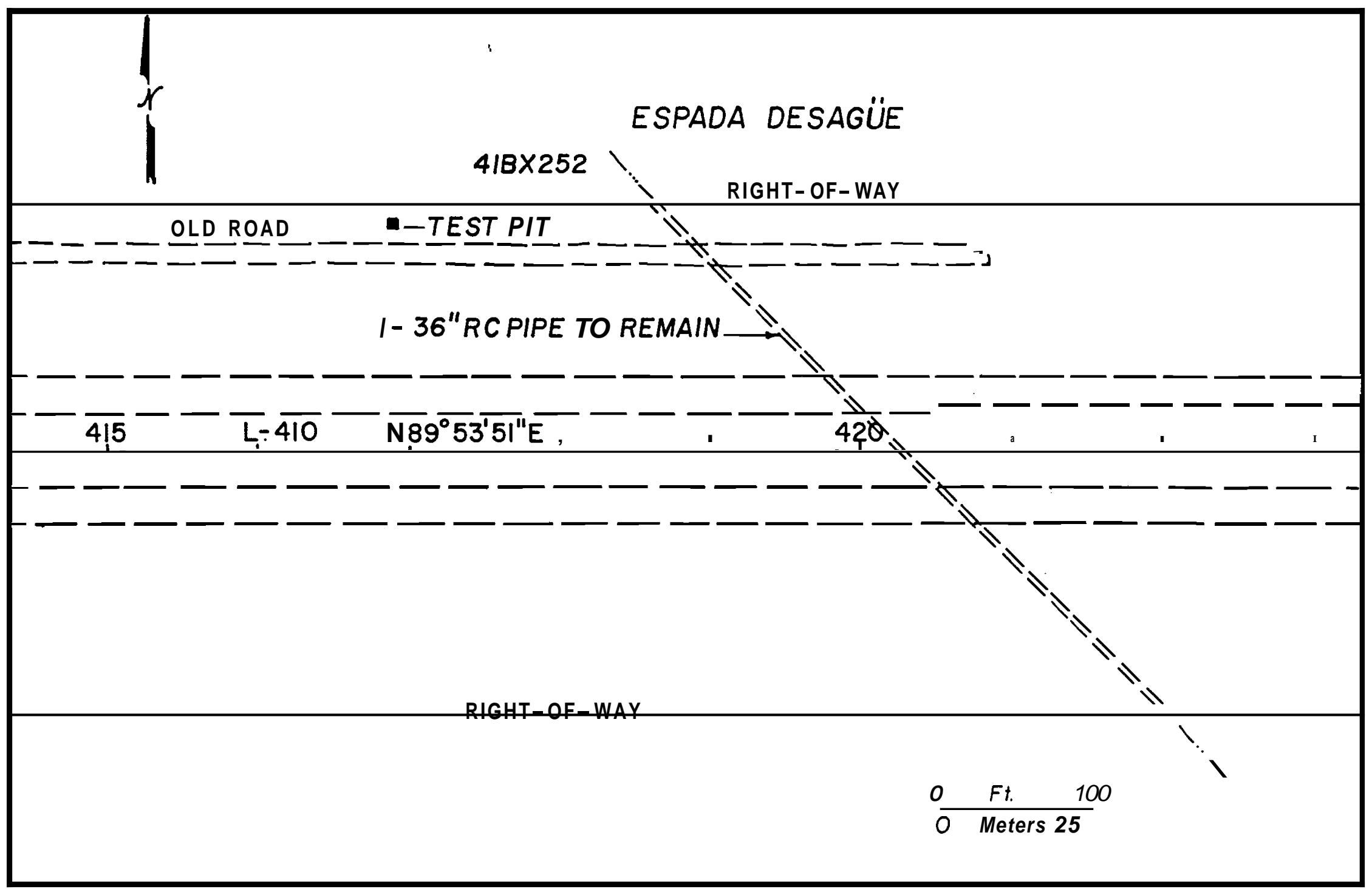

FIGURE 3. Location of test pit near the Espada desague and Site 41BX252. 


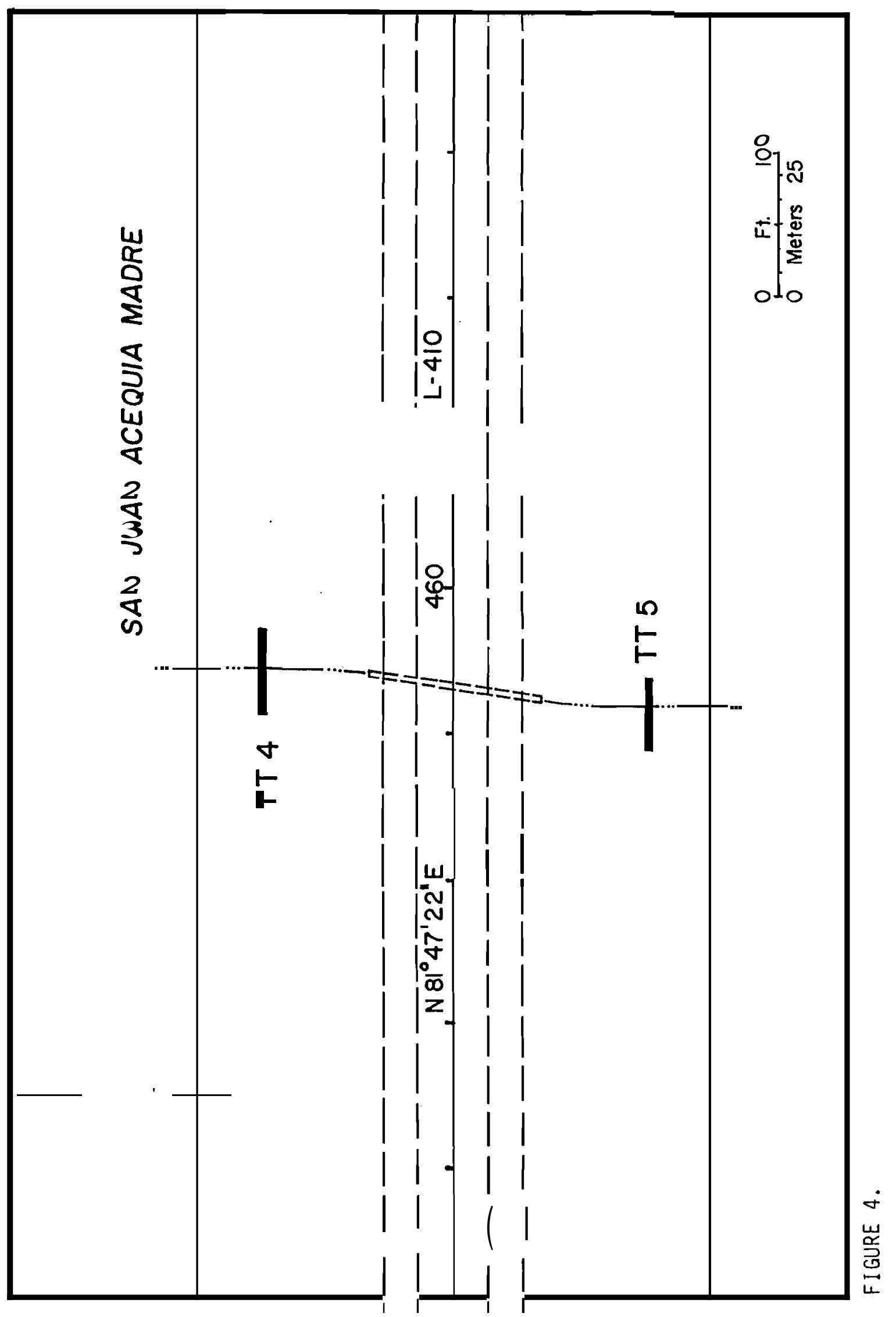




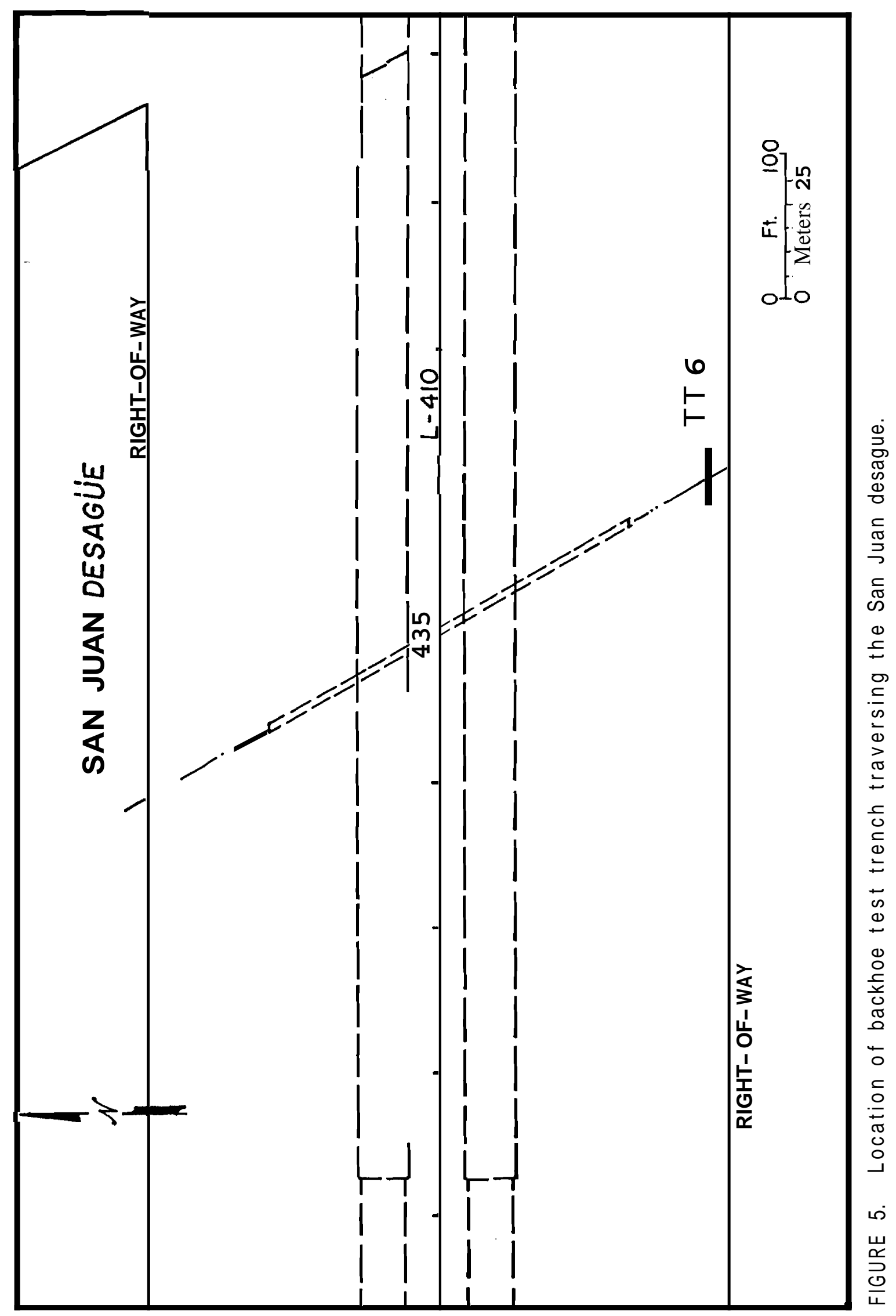




\section{TESTING RESULTS}

\section{Test Trench 1}

No heaped-up spoil deposit was noted on the surface prior to excavation. The trench was excavated to a depth of almost a meter and was about 9.5 meters long. In the lower portion of the trench was dark-brown undisturbed clay. Overlying this clay were alternating strata of caliche in a darkbrown clay (Fig. 6). Originating within $20 \mathrm{~cm}$ of the surface was a trash pit about 1.5 meters in diameter at its center and extending beyond the base of the trench.

The trash pit contained an 18-in. diameter blue graniteware wash basin with two handles and 3 glass bottles. The first bottle is a catsup bottle with a continuous-thread and snap-on closure. It was made by the Hazel Atlas Glass Company between 1920 and 1964 (Toulouse 1971:239). The second bottle is a rectangular panel bottle with a continuous-thread closure made between 1929 and 1954 by Owens Illinois Glass Company (Toulouse 1971:403). The third bottle is a square textured panel bottle with a continuous-thread closure a Iso made by Owens Illinois between 1929 and 1954 (Toulouse 1971:403).

A small number of egg-shell fragments and a small piece of sheet iron also were collected. All of the bottles were clear selenite bleached specimens. The graniteware wash basin was not collected. No other artifacts were collected from this trench. 







\section{Test Trench 2}

Like $\Pi 1$, there was no heaped-up spoil bank observable on the surface. The basal soil was a medium-brown clay overlain by dark-brown clay. Mediumbrown clay formed the upper deposit. A patch of gravel lay near the west end of the trench (Fig. 6). A total of 4 glass sherds was found in the upper 2-3 cm of the west fourth of the trench. The first is a basal fragment of a blue pressed-glass bowl; 2 appear to be selenite bleached bottle body sherds; and the fourth specimen is a pressed-glass Iid fragment.

A house apparently constructed in the 1930 s or 1940 s is situated just south of the right-of-way. This structure appears to be the origin of the artifacts.

\section{Test Trench 4}

This trench was dug to a depth of about 1.5 meters and a length of 16.5 meters through the San Juan acequia madre on the north side of IH 410 . The basal deposit is a dark-brown clay overlain on the east side by a layer of road gravel and medium-brown clay. On the west end of the trench is a berm consisting of medium-brown clay, caliche, red-brown clay, and dark-brown clay in mixed layers apparently associated with highway construction. In the ditch is a mixed zone of dark-brown clay with some caliche. No artifacts were found while digging this trench. 


\section{Test Trench 5}

TT 5 was excavated for a length of 14.5 meters and a depth of 1.5 meters. The basal component of the deposit consisted of a dark, medium-brown clay overlain by medium-brown clay and medium-brown clay mixed with caliche (Fig. 6). A berm was present on the west side of the ditch. No artifacts were noted in the excavation of the trench. The trench was excavated on the south side of I H 410 at the San Juan acequia madre.

\section{Test Trench 6}

Test trench 6 was located on the south side of IH 410 at the San Juan desague and adjacent to the south right-of-way line. The basal deposit is a medium-brown dense clay overlain by a caliche zone and alternating layers of light- or medium-brown clay and a thin caliche zone (Fig. 6). No berm was present in the right-of-way.

\section{Site 41BX252 Test Pit}

The test pit was situated on the north right-of-way line and was a 1 - by 1-meter square excavated to a depth of $5-10 \mathrm{~cm}$ below the surface. The deposit consisted of medium-brown clay mixed with gravel. The percentage of gravel increased rapidly with depth. The matrix was passed through a 
0.25-in. screen and artifacts were collected in a labeled bag. The artifacts recovered in the test $p$ it include 14 green glass jar neck sherds of a single jar having a snap-on cap closure of modern design, 2 amber bottlebody sherds from modern beer bottles, a clear selenite bleached bottle-body sherd with a dimpled band, 1 aluminum twist-off RC Cola bottle cap, 1 welding rod fragment, and 2 fragments of clear sheet plastic. All of this material was encountered in the upper $2 \mathrm{~cm}$ and none below this depth. These items appear to have been deposited within the last 15 to 20 years.

\section{Additional Observations}

In addition to the results of backhoe and hand testing, several observations were made that have a bearing on the evaluation of the project. It was noted that in the area of the Espada acequia madre, there was no spoil bank or berm present within the right-of-way, but a berm was present outside the right-of-way. There also was no berm present on the San Juan desague within the right-of-way, but a berm was distinct outside the right-of-way. Although a berm was present on the west side of the San Juan acequia madre within the right-of-way, it was noticeably lower and broader than the berm outside the right-of-way. In all cases, the ditches in the right-of-way were less steep and shallower.

There were no Spanish Colonial or nineteenth century artifacts encountered during the testing. The artifacts that were found adjacent to the Espada acequia appear to relate to an adjacent 1930s or 1940s house. It can be 
concluded that the acequias and desagues within the present right-of-way were significantly disturbed during original construction of $\mathrm{IH} 410$ and that they, as segments of the undisturbed acequia systems of San Antonio, do not contribute to the historic character of the San Antonio Missions National Park and do not meet the criteria for nomination to the National Register of Historic Places. It can also be concluded that no intact part of Site 41BX252 lies within the right-of-way, the site being located entirely north of the right-of-way. Since these features do not meet the criteria for nomination to the National Register, they also do not meet the criteria for nomination as State Archeological Landmarks. 


\section{REFERENCES CITED}

Carr, John T., Jr.

1967 The Climate and Physiography of Texas. Report 53. Texas

Water Development Board, Austin.

Clark, John W., Jr.

1978 Mission San Jose y San Miguel de Aguayo Archeological

Investigations, December 1974. Report 29. Office of the

State Archeologist, Texas Historical Commission, Austin.

Clark, John W., Jr., and Elton R. Prewitt

1979 Archeological Test Excavations in Areas to be Affected by a

Proposed French Drain West of the Granary, Mission San Jose State Historic Site (41BX3), Bexar County, Texas. Reports of Investigations 3. Prewitt and Associates Inc., Consulting Archeologists, Austin.

n.d. Testing a Colonial Period Dump at Mission San Juan Capistrano in San Antonio, Texas. Notes on file at the office of the State Archeologist, Austin.

Cox, I. Waynne 1986

Excavations of Portions of the San Pedro Acequia (41BX337) and a Search for the Arocha Acequia, San Antonio, Texas. Report 161. Center for Archaeological Research, The University of Texas at San Antonio.

Davis, William B.

1978 The Mammals of Texas. Bulletin 41. Texas Parks and Wildlife Department, Austin.

Eaton, Jack D. 1980 Excavations at the Alamo Shrine (Mission San Antonio de Valero). Special Report 10. Center for Archaeological Research, The University of Texas at San Antonio.

Fox, Anne A.

1978 Archaeological Investigations of Portions of the San Pedro and Alazan Acequias in San Antonio, Texas. Report 49. Center for Archaeological Research, The University Texas at San Antonio.

1985 Testing for the Location of the Alamo Acequia (41BX8) at Hemisfair Plaza, San Antonio, Texas. Report 142. Center for Archaeological Research, The University of Texas at San Antonio. 
Fox, Anne A., Ferris A. Bass, Jr., and Thomas R. Hester

1976 The Archaeology and History of Alamo Plaza. Report 16. Center for Archaeological Research, The University of Texas at San Antonio.

Fox, Anne A., and Thomas R. Hester

1976 Archaeological Test Excavations at Mission San Francisco de Ia Espada. Report 22. Center for Archaeological Research, The Universi ty of Texasat San Antonio.

Fox, Daniel E.

1970 Archeological Salvage at Mission San Jose, December 1969, April and August 1970. Texas Historical Survey Committee. Austin.

Frkuska, Augustine J., Jr.

1981 Archaeological Investigations at the San Pedro Acequia, San

Antonio, Texas. Report 103. Center for Archaeological

Research, The University of Texas at San Antonio.

Glick, Thomas F.

1972 The Old World Background of the Irrigation System of San

Antonio, Texas. Monograph 35. Texas Western Press

Southwestern Studies, The University of Texas at EI Paso.

Gould, F. W.

1969 Texas Plants: A Checklist and Ecological Summary. Texas A\&M

University, Texas Agricultural Experiment Station, MP-585.

College Station.

Greer, John W.

1967 A Description of the Stratigraphy, Features and Artifacts from an Archeological Excavation at the Alamo. Report 3. State Building Commission Archeological Program, Austin.

Henderson, Jerry, and John W. Clark, Jr.

1984 The Acequia and Other Features at Mission San Jose, Bexar

County, Texas, Publications in Archaeology Report 25. Texas

State Department of Highways and Public Transportation,

Highway Design Division, Austin.

Holmes, WIlliam Henry

1962 The Acequias of San Antonio. M.A. thesis, St. Mary's

University, San Antonio.

Schuetz, Mardith K.

1966 Historic Background of the Mission San Antonio de Valero.

Report 1. State Building Commission Archeological Program, Austin.

1968 The History and Archeology of Mission San Juan Capistrano, San Antonio, Texas, vol. I. Report 10. State Building Commission Archeological Program, Austin. 
Schuetz, Mardith K. (

1969 The History and Archeology of Mission San Juan Capistrano, San Antonio, Texas, vol. II. Report 11. State Building Commission Archeological Program, Austin.

1970 Excavation of a Section of the Acequia Madre in Bexar County, Texas, and Archeological Investigations at Mission San Jose in April 1968. Report 19. Texas Historical Survey Committee, Austin.

1974 The Dating of the Chapel at Mission San Juan Capistrano, San Antonio, Texas. Special Report 2. Office of the State Archeologist, Texas Historical Commission, Austin.

Scurlock, Dan, Adan Benavides, Jr., Dana Isham, and John W. Clark, Jr. 1976 An Archeological and Historical Survey of the Proposed Mission Parkway, San Antonio, Texas. Report 17. Office of the State Archeologist, Texas Historical Commission, Austin.

Scurlock Dan, and Daniel E. Fox

1977 An Archeological Investigation of Mission Concepcion, San Antonio, Texas. Report 28. Office of the State Archeologist, Texas Historical Commission, Austin.

Sorrow, William M.

1972 Archeological Salvage Excavations at the Alamo (Mission San Antonio de Valero) 1970. Research Report 4. Texas Archeological Salvage Project, The University of Texas at Austin.

Taylor, F.B., R.B. Hailey, and D.L. Richmond

1966 Soil Survey of Bexar County, Texas. Series 1962:12. U.S. Department of Agriculture, Soil Conservation Service, Washington, D.C.

Toulouse, Julian $\mathrm{H}$.

1971 Bottle Makers and Their Marks. Thomas Nelson, Inc., New York.

Tunnell, Curtis

1966 A Description of Enameled Earthenware from an Archeological Excavation at Mission San Antonio de Valero (the Alamo). Report 2. State Building Commission Archeological Program, Austin. 